\title{
AC 2011-401: PART-TIME FACULTY IN ENGINEERING TECHNOLOGY
}

Terri L. Talbert-Hatch, Indiana University Purdue University, Indianapolis

Terri Talbert-Hatch is the Assistant Dean for the Purdue School of Engineering and Technology, IUPUI. In this position she is responsible for recruitment of undergraduate students and all scholarships. She is responsible for all marketing for the school including program brochures and the school's website. She also oversees the School's Career Services office and is the advisor to the school's student council. She received her Bachelor's in General Studies and M.S. in Adult Education at IUPUI. She is currently working on her dissertation toward an Ed.D. in Higher Education Administration at Indiana University.

\section{Stephen Hundley, Indiana University-Purdue University Indianapolis}

Stephen P. Hundley is Associate Dean for Academic Affairs and Undergraduate Programs and Associate Professor of Organizational Leadership in the Purdue School of Engineering and Technology at Indiana University-Purdue University Indianapolis (IUPUI). 


\title{
Part-time Faculty in Engineering Technology
}

\begin{abstract}
Many engineering technology programs in the United States employ part-time faculty to augment the work of full-time faculty, manage enrollment and employment fluctuations, and provide subject-matter-expertise that may otherwise be lacking in a particular context, among other reasons. The preparation, performance, and impact of part-time faculty is significant, as higher education leaders and external stakeholders press for quality, accountability, and continuous improvement of programs and institutions. Thus, a challenge for engineering technology programs is to make certain that part-time faculty members possess both the academic and professional qualifications for employment, and to ensure that these colleagues are appropriately supported in order to be effective in their role.
\end{abstract}

This paper presents results of a qualitative study of part-time faculty members in engineering technology and other disciplines, notably liberal arts, at Indiana University-Purdue University Indianapolis (IUPUI). The rationale for employing part-time faculty, institutional types that most heavily rely on part-time faculty, the strengths and challenges associated with part-time faculty, and the relationships between full-time faculty and part-time faculty will be described. Specific attention will be paid to the reasons part-time faculty seek affiliation with the institution, the expectations part-time faculty have concerning their role, and the self-reported satisfaction levels of part-time faculty. Examples of part-time faculty perspectives from engineering technology will be examined, compared, and contrasted with those of other disciplines, and a series of recommendations for key stakeholder groups will be provided.

\section{Introduction and Significance}

Both two-year and four-year higher education institutions employ part-time faculty in large numbers, and this is especially true for engineering/technology disciplines located in urban and metropolitan settings. Two U.S. Department of Education studies conducted in 1992 and 2003 provided statistics that support the fact that the percentage of part-time faculty in higher education is remaining constant ${ }^{1}$. According to the later study, $43.7 \%$ of all faculty and instructional staff were employed on a part-time basis. Higher education institutions employ faculty on a part-time basis for a variety of reasons, which often revolve around cost saving measures ${ }^{2,3}$. Part-time faculty can also be hired quickly when there are unexpected increases in enrollment because there is more flexibility in their hiring process ${ }^{4,5,6,7}$.

With nearly half of all faculty employed part-time, research and the need for more information on this group has increased. However, much of that research has emphasized working conditions and portrays part-time faculty as individuals who cannot obtain a full-time teaching position. Thus, there is a gap in the literature as to why part-time faculty choose to teach part-time, their satisfaction and commitment ${ }^{8}$. Wallin ${ }^{9}$ said it is important for college administrators to understand what motivates part-time faculty. The large number of part-time faculty and this literature gap regarding part-time faculty satisfaction and the need to understand their motivation led to the desire to discover the motivation of part-time faculty at the large, urban university that is the focus of this study. 


\section{Literature Review}

The phenomenon of hiring part-time faculty at higher education institutions is not new. However, the employment of part-time faculty has grown tremendously. This growth has brought about an interest and concern regarding this population. Research and hard evidence had been lacking until 1988 when the National Education Association drafted a policy statement that advocated for the reduction in part-time faculty. This policy statement, as well as others in the future, addressed the use of part-time faculty based on negative assumptions ${ }^{10}$.

It is important to know the history of employing part-time faculty, to understand the demographics of this population, and reasons institutions are increasing their reliance on a parttime workforce. Only then can we better understand the concerns raised about part-time faculty employment. Beyond these issues, this literature review will explore employment practices, perceptions of part-time faculty by others, concerns of part-time faculty, motivations of part-time faculty, and workplace motivation theory. This framework will be beneficial to fully understand additional issues regarding motivation of part-time faculty.

\section{History of the Utilization of Part-Time Faculty}

Part-time faculty in colleges and universities is an established tradition. Since the early nineteenth century, colleges and universities employed ministers and scholars from other institutions as teachers ${ }^{11}$. The use of part-time faculty in professional areas continued to grow in the post-Civil War era as colleges added new areas of learning. Even medical practitioners joined faculty as clinical appointees. For much of the twentieth century, universities have sought to employ faculty who would bring attention and prestige; such as political figures, artists, renowned physicians and scientists. Many of these faculty positions have been part-time, as their incumbents may have instructed no more than one class a year. The use of clinical appointments and appointments of public figures constituted the majority of part-time faculty appointments until after World War II ${ }^{12}$.

The end of World War II saw a rapid expansion in higher education. Many factors are associated with this expansion including the GI Bill, which paid for the education of many returning war veterans. Other reasons for the growth of education include the introduction and growth of junior and community colleges, the changing economy, and the availability of other government funds to pay or assist with the payment of college tuition. The subsequent rapid growth in enrollments resulted in the need for more faculty, which is one of the main reasons for the increased use of part-time faculty. In the peak years of baby boom enrollments, the use of part-time faculty increased considerably, reaching $22 \%$ in $1970^{11}$. In some areas, state university branches were set up in underserved areas to relieve the crowding of central campuses. The offerings at these "regional" campuses were replications of the main campus. Faculty from the "main" campuses were not interested in commuting to the regional locations to teach. With the rapid growth of these regional campuses, which had an emphasis on teaching and large increases in the number of students, part-time faculty were hired, frequently based on last minute registration counts ${ }^{12}$. 
Junior and community colleges, which became a phenomenon in the twentieth century, have always employed part-time faculty. When most of these colleges were small, administrators hired secondary school instructors to teach courses such as physics, chemistry, and biology rather than have a single instructor present all the college courses in the sciences ${ }^{13}$. University professors also taught at community colleges on a part-time basis. Part-time faculty also offered specialized courses in which current faculty and staff did not have subject matter expertise. In 1969 approximately $27 \%$ of faculty at community colleges were part-time and that grew to $52 \%$ in $1987^{14}$.

The use of part-time faculty shows no signs of slowing. The number of part-time faculty increased by $133 \%$ from 1971 to 1986; full-time faculty increased by only $22 \%$ during that same period $^{15}$. Between 1975 and 1995, part-time faculty appointments increased by $103 \%$ and nontenure track appointments by $92 \%$, in contrast to a $12 \%$ decline in probationary tenure-track positions ${ }^{16}$. Part-time faculty represent a very diverse group of individuals. In order to relate and understand the literature on part-time faculty it is important to review the varied definitions and demographics of part-time faculty.

\section{Definitions and Demographics}

The terms part-time and full-time faculty are commonly used to differentiate faculty members. "The term part-time faculty should mean persons who are employed by a university to perform some typical faculty function (that is, teaching, research, or professional service) but who do not or cannot commit their full and complete professional efforts to the purposes of the university in a manner typical of regular faculty" ( $\mathrm{p} 41)^{17}$.

\section{Definition of Part-time Faculty}

Educational researchers such as Tuckman, Caldwell, \& Volger ${ }^{18}$ were among the first to define categories for part-time faculty, which included:

- $\quad$ Semi-retireds - former full-time academics, whose focus is not about future job prospects

- Graduate students - full-time graduate students who teach part-time to gain experience

- Hopeful full-timers - individuals who teach part-time only because they have not been successful at obtaining a full-time teaching position or began teaching part-time in the first place in hopes of moving into a full-time position.

- Full-mooners - individuals who hold a full-time job outside of higher education and teach in a subject matter where they have expertise. Their reasons are various, but often revolve around enjoying the status of university affiliation.

- Homeworkers - individuals who teach part-time because they have the responsibility of taking care of a relative or child and enjoy the flexibility afforded by teaching part-time.

- Part-mooners - individuals that hold two or more part-time jobs, of which teaching is only one of the jobs. They may often be motivated by the stable source of supplementary income.

- Part-unknowners -- this category includes part-time faculty whose reasons for teaching part-time are either unknown or individual 
Gappa and Leslie ${ }^{10}$ used these categories in conducting a survey of 467 chief academic officers, deans, department heads, and full- and part-time faculty members at eighteen institutions. Based upon the results of the survey, the categories were broadened into four loose categories: career enders; specialists, experts, and professionals; aspiring academics; and free lancers. The career enders category is defined as individuals who are retired as well as those in transition to retirement from higher education and other professional careers. The specialist, expert, or professional category is the same as Tuckman, Caldwell and Volger's ${ }^{18}$ full-mooner individuals working full-time outside of the university. Aspiring academic relates to the hopeful full-timer category. This group is sometimes referred to as freeway fliers, referring to their pattern of commuting from one institution to the next to compile full-time employment from separate part-time contracts. The last group, freelancers, is a composite of part-unknowners, partmooners, and homeworkers.

\section{Demographics of Part-time Faculty}

The National Center for Education Statistics, U. S. Department of Education, conducted the largest survey of part-time faculty to date, during fall $2003^{1}$. Data collected from more than 26,100 faculty and instructional staff with regard to the population of part-time faculty at U. S. public and private institutions indicated the following statistics:

- Approximately $43.7 \%$ of all faculty are part-time.

- At public doctoral institutions $22.2 \%$ of faculty are part-time, $36.7 \%$ are part-time at public master's institutions, and $66.7 \%$ of faculty are part-time at public associate's institutions.

- At private institutions the percentage of part-time faculty is greater: $31.4 \%$ at doctoral institutions, $54.9 \%$ at master's institutions, and $36.8 \%$ at baccalaureate institutions.

- Sixty-eight percent of all full-time faculty are either tenured or on tenure track. Only $4.5 \%$ of part-time faculty are in that same category.

- Total earned income for full-time faculty is $\$ 81,200$, which includes $\$ 67,400$ from the institution, $\$ 5,000$ of other income from the institution, $\$ 2,200$ from outside consulting, and $\$ 6,600$ from other outside income. Other income from the institution includes summer sessions, overload courses, administration, research, etc. This compares to $\$ 52,500$ for part-time faculty of which $\$ 11,200$ was from the institution, $\$ 900$ other income from the institution, $\$ 2,900$ from outside consulting, and $\$ 37,500$ from other outside income. Part-time faculty included all part-time instructional staff whether or not they had other types of income.

- The study also showed that $18.5 \%$ of part-time faculty have obtained a doctoral degree compared to $61 \%$ of full-time faculty and $51.3 \%$ of part-time faculty obtained a Master's degree compared to $25.4 \%$ of full-time faculty.

\section{Reasons Institutions Employ Part-Time Faculty}

Colleges and universities employ part-time faculty for many legitimate economic and educational reasons. The literature cites several reasons for the increasing employment of part-time faculty - fiscal issues, which include decreasing state support and enrollment 
fluctuations; flexibility in terms of curricula offering; and course offering times and locations outside of what could be called normal business hours on campus ${ }^{10}$. A common perception is that the number of part-time faculty are increasing only due to budget constraints and to save on the cost of salaries and benefits ${ }^{19}$.

Part-time faculty represent a cost savings when compared to full-time faculty because they are compensated approximately one-quarter that of full-time faculty ${ }^{20}$. In a study based on 20032004 and 2004-2005 National Center for Education Statistics compensation data, Curtis and Jacobe $^{21}$ found that part-time faculty were paid less per credit hour than full-time faculty and specifically part-time non tenure track faculty were paid $64 \%$ less than tenured professors. In addition, most part-time faculty do not receive benefits ${ }^{22}$. Researchers have expressed concerns that as colleges and universities continue to look for ways to cut budgets, the number of parttime faculty will continue to increase while the number of full-time faculty declines. There is also a concern that more faculty retirees will be replaced with part-time faculty as a cost containment strategy ${ }^{19}$.

Part-time faculty are normally appointed on renewable contracts versus having the assurance of continued employment that comes with tenure. This provides colleges and universities flexibility in terms of scheduling classes in times of budget concerns associated with fluctuating state funding and/or student enrollment ${ }^{4,5}$.

A major reason for employing an increasing number of part-time faculty at universities is enrollment fluctuation. External factors affect enrollment and the need for instructional faculty; changes in the economy and changes in the availability of loans and grants affect enrollment; and changes in the job market affect the choice of majors and the demand for particular courses ${ }^{11}$. Most part-time faculty are compensated according to the number of courses taught. Their contracts are on a semester-by-semester basis and can be terminated if enrollments are down ${ }^{23}$. In this way, higher education administrators can hedge against enrollment fluctuations without the investment of mandated funds used to cover salary and benefits of tenured faculty.

Outside of simple financial reasons, part-time faculty are hired for many reasons which include: specific knowledge and expertise, flexibility, ability to teach at odd hours and at off-campus locations ${ }^{5}$. Disciplines such as business, law, engineering, and health-related areas employ a high percentage of part-time faculty due to the value of such practitioners in the classroom ${ }^{24}$. The "real world" experience that these individuals bring to the classroom is a valuable tool ${ }^{19}$. The reliance on part-time faculty in departments such as English and Mathematics are due in large part to increasing enrollments and also to replace full-time teachers in these core subjects who prefer to teach upper level or graduate courses ${ }^{16}$.

The use of part-time faculty is justified by economic and educational constraint. The reasons for employing part-time faculty are logical. Part-time faculty have become an indispensable force in higher education ${ }^{25}$. Administrators have developed practices that separate part-time from fulltime faculty in many ways. Not only do benefits and salaries separate part-time from full-time faculty, but employment practices are also handled separately and very differently for the two categories of faculty members. These differences may result in part-time faculty feeling inferior 
and less satisfied with their employment ${ }^{9}$. This separation results in two classes of higher education faculty.

\section{Employment Policies and Practices}

Policies and practices related to hiring, orientation, evaluation, and professional development of part-time faculty are totally separate from those for full-time employees. In many instances, an institution may not have written employment policies for part-timers. When colleges and universities do have policies and practices for part-time faculty, they are not as extensive as those for full-time employees and these usually exist only at an organized or union institution ${ }^{3}$. This inconsistency in employment policies cannot ensure that part-time faculty are treated fairly and consistently and provided the tools to effectively do their jobs ${ }^{10}$.

All faculty members have contact with students in the classroom. Therefore, an assumption could be made that the qualifications and teaching experience of all prospective faculty should be highly scrutinized and the same requirements be desired of all. However, the separation of fulltime and part-time faculty begins in the hiring process.

\section{Hiring and Contracting}

The hiring process for part-time faculty is usually informal. The position may be advertised locally, but part-time faculty are often recruited by word-of-mouth ${ }^{4}$. The department chair most often handles the hiring process and full-time faculty have little involvement in the hiring process $^{3}$. This process may result in a very casual selection process. Department chairs have concerns that this type of hiring process will undoubtedly produce a few failures every year ${ }^{10}$. This hiring process, which is a much less strenuous process than that for tenure-track faculty, may result in the hiring of a part-time faculty who has a lack of knowledge about the student population, overall curriculum, and a lack of connection with the department ${ }^{9}$.

The interview process is one of the challenges in the hiring process not just for the institution, but also for the candidates. Van De Vorn ${ }^{26}$ highlights how important it is for candidates to clearly understand their own motives and values in applying for the faculty position. Few parttime faculty have any type of contractual protection in hiring and also in release or firing ${ }^{3}$. The discretion of department chairs in the hiring and firing process is also noted in the literature as problematic. Many part-time faculty are often not provided a realistic job preview, especially related to expectations of future employment opportunities ${ }^{27}$. "Most part-timers are appointed term by term and notification of an appointment or renewal often comes very late. Part-timers are left with little time to prepare, which can have a deleterious effect on the quality of their teaching performance" (p. 80) ${ }^{4}$.

The hiring and contracting process does have an advantage for higher education institutions. Part-time faculty who do not receive positive student evaluations or do not measure up to expectations do not have to be reappointed ${ }^{10}$. "Although an institution might make a strategic mistake by granting tenure to a full-time faculty member who is a poor teacher, it almost never retains a part-time faculty member who has difficulty in the classroom. In a sense, then, part-time faculty may be held to a higher standard of teaching performance on the average" (p. 125) ${ }^{10}$. 


\section{Orientation and Professional Development}

In addition to advance notice of teaching opportunities, scholars note that better orientation at the beginning of employment would help part-time faculty get up to speed on expectations and their job in general ${ }^{10,27}$. Often, the work schedules of part-time faculty who work other jobs during the day are not taken into consideration when orientation sessions are scheduled ${ }^{28}$. A better understanding of expectations can result in more prepared and satisfied part-time faculty.

Surveys regarding the availability and utilization of professional development funds indicate several differences between full-time and part-time faculty regarding opportunities for professional development ${ }^{29}$. Schuetz ${ }^{7}$ found that both full- and part-time faculty planned to take advantage of professional development opportunities. In addition, this study also revealed that full-time faculty were more likely to attend organization meetings and academic and professionally related conferences. Full-time faculty were also more likely to join disciplinary, non-disciplinary, and college related organizations. In her conclusion, Schuetz ${ }^{7}$ suggested that "part-time faculty are less connected than full-time faculty to professional organizations, colleagues, and administrative activities, all of which support and are likely sources of information about effective instructional practices" (p. 43) ${ }^{7}$.

A study of community colleges ${ }^{30}$ found that nearly half of the community colleges surveyed provide professional development opportunities for part-time faculty. In addition, 53\% provided travel funds for both full- and part time faculty. The results of the survey suggested that Community Colleges are making efforts to integrate professional development opportunities for both full-time and part-time faculty.

In looking at the extent to which faculty read to advance their professional development, a Gappa and Leslie ${ }^{31}$ survey found "no statistically significant difference between part-time and full-time faculty with respect to disciplinary journals, general media dealing with higher education, and journals focusing specifically on community colleges. Full-time faculty are slightly more disposed to read discipline-based journals. Part-time faculty do not report spending a substantially different amount of time on professional development" (p. 61) ${ }^{31}$.

A study by Keim and Biletzky ${ }^{35}$, which focused on professional development and evaluations of part-time faculty at community colleges, found that there was a need for development activities and thorough teaching evaluations. They recommended that part-time faculty receive feedback from peers and administrators on their teaching in addition to student evaluations. They suggested that the student end-of-course evaluations were often incomplete and did not provide enough detail to improve teaching and classroom performance.

Roueche, Roueche, \& Milliron ${ }^{36}$ found that community college administrators felt their abilities to provide professional development opportunities for part-time faculty were often limited by the time constraints of part-timers and the unwillingness of the campus to provide compensation for participation in these programs. Part-time faculty typically felt that they were provided limited opportunities and incentive for professional development. This resulted in feelings of alienation and concern. The surveys reveal that there is some effort made by administrators to provide 
part-time faculty with opportunities for professional development and that part-time faculty are making efforts to use the professional development opportunities available.

\section{Integration of Part-time Faculty}

"Integration is our word for the effort institutions make to ensure that their part-time faculty members are successful, valued, and supported in what they do" (p. 180) ${ }^{10}$. However, few college administrators are aggressively directing efforts toward integration of part-time faculty often do not feel connected to and integrated into the department and the campus ${ }^{27}$. They state that they feel powerless and isolated and are treated as "second-class citizens" in a two-tier system $^{16}$. This can suggest not only isolation from colleagues, but also knowledge regarding innovative teaching and campus services from which they and students may be able to benefit. Part-time faculty on average, have substantial teaching experience, are less likely to have taught courses jointly with other faculty members, and are more likely to have spent no time in administrative activities and departmental committees ${ }^{7}$.

Gappa and Leslie ${ }^{32}$ found that when part-time faculty feel integrated into the campus, it is usually at the department level and based upon departmental culture, which includes attitudes of tenured faculty, department leadership, and the level of participation sought by part-time faculty ${ }^{10}$. When departments are concerned about teaching and student learning, an atmosphere of collaboration and conversation regarding these issues is more active and inclusive of all. These departments involve part-time faculty and are open to their comments and suggestions ${ }^{32}$. The more proactive an institution is by creating a culture that embraces part-time faculty by providing both opportunities and responsibilities for them, the less hostile the climate towards part-time faculty. This lack of hostility results in greater satisfaction for part-time faculty. When part-time faculty are not engaged and treated with respect, the coherence of academic programs and quality of instruction can be damaged ${ }^{32}$.

Another issue with the integration of part-time faculty relates to time on campus. Many parttimers are hired to teach evening, weekend, and off-campus classes. Lack of department office space is another constraint ${ }^{5}$. Part-time faculty often work without normal support services that full-time faculty take for granted such as offices and secretarial support ${ }^{11}$. Since most offices are staffed only during week-days, part-time faculty who teach at odd hours may be required to turn in requests for services several days in advance. With office space at premium on most campuses, part-timers are often housed in "bull pen" offices because that is all that may be available ${ }^{10}$. Additional perceived issues regarding the continued hiring of part-time faculty include teaching methods and student contact as well as replacement of tenured positions.

\section{Perceived Issues and Concerns Regarding Part-Time Faculty}

The common image of part-time faculty frequently portrayed in literature is of a dissatisfied workforce whose members hold several part-time teaching positions at different institutions to constitute a full-time job ${ }^{31}$. Today, the majority of part-time faculty are employed full-time outside of the teaching position and are not seeking full-time employment in higher education ${ }^{27}$. Part-time faculty are more often motivated to teach based upon intrinsic rewards and not for economic purposes ${ }^{31}$. Many part-time faculty teach because they like to teach, they enjoy making 
a contribution to students and the affiliation with the institution, and because of a desire to keep current with the professional literature ${ }^{33}$. However, the perception that part-time faculty are less effective instructors and do not provide a quality education continues. This feeling can lead to dissatisfaction and lack of motivation. ${ }^{4}$

\section{Contributions to Student Learning}

A very important concern regarding part-time faculty is the "perception that they threaten the quality of academic programs in terms of course content, advising, faculty-student interaction, and collegiality with academic departments" (p. 85) ${ }^{34}$. Gappa \& Leslie ${ }^{10}$ found little evidence regarding the negative impact part-time faculty had on the quality of academic programs and that they are qualified for their teaching assignments and committed to their job. Hellman ${ }^{37}$ found that student evaluations of full- and part-time faculty differ little. A similar study by Landrum ${ }^{38}$ had similar results find no significant differences. So the debate continues regarding the increased utilization of part-time faculty. While some contend that part-time faculty, especially in the professional schools, bring valuable real-world experience to the classroom, the utilization of effective teaching methods is still in question. In a study conducted by Schuetz ${ }^{7}$, part-time faculty were found to be less likely to have revised their syllabus or teaching objectives in the previous three years, to have used multimedia instruction in the class, and to have developed extracurricular activities for students. Similarly, Schuster ${ }^{39}$ found part-time faculty use technology less and are less current in their academic discipline. Benjamin ${ }^{16}$ also found part-time faculty use technology less and they also have lower writing expectations. Umbach ${ }^{40}$ found that "part-time faculty use active and collaborative techniques less often, spend less time preparing for class, and have lower academic expectations for their students than their tenured and tenure track peers" (p. 110) ${ }^{40}$.

Another concern expressed about part-time faculty are the inconsistencies that result when there are multiple offerings of a class with some taught by part-time faculty and some taught by tenured faculty ${ }^{41}$. Many part-time faculty are involved in teaching lower-division, general education classes and therefore, new students are taught by a substantial number of part-time faculty ${ }^{5}$. In general, student evaluations are equivalent for full-time and part-time instructors in these general education classes34. "Typically, full-time faculty are more accessible to students, have offices and office hours, are familiar with the institutional services available to students and have an understanding of grading and performance norms for the courses they teach. This means that students can have a significantly different educational experience, particularly in regard to their access to faculty members, based on arbitrary scheduling decisions" (pp. 13-14) ${ }^{41}$.

In a study that focused on sequential courses of developmental mathematics and regular mathematics with a focus on instructor status, the results indicated that students who took the first course with a part-time instructor followed by a full-time instructor were less likely to complete the second course. The data indicated that in sequential college courses, part-time faculty instructors underprepared their students for subsequent courses taught by full-time faculty $^{42}$. Boyland ${ }^{43}$ stated that over $60 \%$ of the developmental courses offered at community colleges are taught by part-time faculty. 
The consistency of instruction and information dissemination in classes taught by both part-time and full-time faculty is often questioned. To counter this, textbooks and supplemental readings are often selected and approved by department chairs and curriculum review committees ${ }^{44}$. Parttime faculty are generally required to use the approved textbooks.

\section{Student Contact}

Faculty involvement with students is critical to their success and degree completion. Benjamin ${ }^{16}$ reported that part-time faculty spend no more than half the out of class student-related time per class hour as that of full-time faculty. He concluded that part-time faculty devote $25 \%$ or less time per class hour to out of classroom time with students ${ }^{16}$. In addition, part-time faculty are twice as likely to report spending no time outside of the class with students ${ }^{7}$. According to $\mathrm{Umbach}^{40}$,part-time faculty interact less frequently about class-related issues than their permanent faculty peers. Full-time faculty are better situated to spend more time with students outside of the classroom, if not due to desire, then partly due to convenience. Lack of campus offices and requirements for office hours for part-time faculty contribute to this phenomenon. Part-time faculty are concerned that they are "second class citizens" in higher education. Tenured and tenure-track faculty are concerned that part-timers will replace full-time positions. These two sets of concerns do not make for an atmosphere of collaboration and learning.

\section{Replacement of Tenured Positions}

As stated previously, the reasons for hiring part-time faculty vary by institution and by department; however, the financial constraints imposed on higher education by the leveling off of state funding will continue to support employment of part-time faculty. Many may argue that the increased use of part-time faculty harms full-time faculty by replacing full-time positions and extra pay for course overloads ${ }^{4}$. The replacement of full-time positions is likely to continue as more full-time professionals leave higher education due to retirement and other reasons. Between 1975 and 1995 part-time faculty appointments increased by $103 \%$ and in a more recent survey of mathematics departments, between 1995 and 2000, part-time faculty grew by $35 \%$ and nontenure track positions grew by $65 \%$, while tenured positions declined by $3 \%{ }^{16}$. With no signs of improved funding for higher education, many of these vacancies will continue to be filled with part-time workers ${ }^{19}$.

Another concern of full-time faculty is that with the increasing number of part-time faculty, many non-instructional responsibilities including student advising and committee work are turned over to an ever declining number of full-time instructors. Many times these same fulltime instructors are also asked to assist in the supervising and evaluation of part-time faculty ${ }^{32}$. Haeger $^{34}$ argues that the challenge for institutions is to recognize, not only the economic benefits of part-time faculty, but also the educational value and work to develop policies and strategies that ensure collegiality and collaboration among all faculty appointees, regardless of part-time or full-time status. It is important to establish relationships and communication lines so the best quality of instruction is available to students at all levels ${ }^{32}$. Apparently, the lack of integration of part-time faculty is harmful to all involved - part-time faculty, full-time faculty, and students. It is important not only to understand the concerns of full-time faculty, but also part-time faculty as well. 


\section{Concerns of Part-Time Faculty}

Part-time faculty have been called "exploited workers" due to the low pay, lack of benefits, and poor working conditions ${ }^{10,45}$. However, the perception of part-time faculty as disgruntled employees of higher education institutions is not accurate. Part-time faculty are generally satisfied with the role they have in higher education, but they do have concerns regarding salary, benefits, and job security ${ }^{46}$.

\section{Salary}

Much has been written about the salaries of part-time faculty. Interesting, though, is the fact the American Association of University Professors annual survey of faculty earnings includes only full-time faculty salaries. AAUP's reasoning for the omission of part-time faculty salaries is the likelihood that data would be inconsistent and the format of the survey would have to be adapted as most part-time faculty are compensated based upon credit hour or courses taught compared to annual salaries for full-time faculty.

Since one of the reasons higher education institutions hire part-time faculty is for cost containment, part-time faculty are hired mostly for teaching functions and are paid considerably less per credit hour of teaching than full-time faculty ${ }^{39}$. Studies have been completed to attempt to determine salaries of part-time faculty compared to those of their full-time counterparts. A study completed by Monks ${ }^{45}$ in 2007 showed that part-time faculty earn between $22 \%$ and $40 \%$ less than tenure-track assistant professors on an hourly basis. Another study completed by Jacoby $^{20}$ found that part-time faculty compensation is approximately $25 \%$ of full-time faculty equivalent pay. While it appears difficult to determine on a more accurate level, it is clear parttime faculty are paid substantially less than their full-time counterparts ${ }^{23}$. In addition, while salary policies vary by institution, once hired, most part-time faculty do not always receive cost of living or merit increases ${ }^{10}$.

\section{Benefits and Support}

Part-time faculty often do not feel integrated in the college campus. In many situations, there is also a physical separation. Office space for part-time faculty is generally limited ${ }^{22}$. Some colleges provide one large room or require several part-timers to share an office similar in size to one full-time faculty office ${ }^{44}$. Part-time faculty are often hired to teach evening and weekend classes. This results in a problem obtaining supplies and equipment and secretarial support. In many instances, offices providing this type of support are often closed during times when parttime faculty are on campus and may require advance notice of needs ${ }^{4}$.

It is difficult for the faculty to feel like they are a part of the big picture under these conditions. The message to full-time faculty is that part-time faculty are not important and this is the same message that part-timers receive. In addition, part-time faculty frequently do not have job benefits that their full-time colleagues enjoy. "Part-time faculty are excluded basic work provisions such as sick leave, insurance, and due process rights to grievance and arbitration" ( $\mathrm{p}$. $644)^{3}$. 


\section{Advancement - No Career Ladder}

Part-time faculty, in general, are not looking for full-time academic positions. However, it is often stated that the main disadvantage of working as a part-time faculty is the lack of advancement opportunities and the lack of job security ${ }^{27}$. Many part-time faculty have enjoyed long, productive relations with an institution ${ }^{46}$. The lack of advance notice of teaching schedules, in many cases, helps to create an atmosphere where part-time faculty have no sense of job security. Since part-time faculty are not usually integrated into their departments, they may not fully understand the scheduling process.

\section{Lack of Involvement in Departments}

Both part-time and full-time faculty are aware of a threat to consistency of courses/programs which is enhanced by the lack of part-time participation in department committees and teaching activities $^{32}$. Even though part-time teachers have become a regular fixture on most college campuses, they generally do not have a voice and rarely have been represented on faculty governance bodies ${ }^{47}$. Part-time faculty are often denied a substantive role in academic governance, curriculum development, and other decision processes that affect their own work ${ }^{28}$.

Findings have suggested that higher education institutions consider providing part-time faculty (and other contingent faculty) with support and training that would increase their performance in addition to trust and commitment ${ }^{40}$. Similarly, Boyland ${ }^{43}$ found that programs were more successful when they fully integrated part-time faculty and considered them as assets. Integration was described as providing support mechanisms such as orientation manuals and programs encouraging participation in department meetings and mentoring programs

Benefits, advancement, lack of communication, and integration are some of the most important concerns of part-time faculty that surface in most articles written about part-time faculty. There are other perceptions and concerns of part-time faculty.

\section{Part-Time Faculty Perception of Their Role}

Part-time faculty, in general, appreciate the opportunity to teach at times that do not interfere with full-time jobs, school, and family activities - times which may not be attractive to full-time faculty ${ }^{36}$. Most complaints and concerns expressed by part-time faculty, outside of salaries, involve the second-class status and lack of integration.

With the employment of part-time faculty continuing, researchers have been exploring their job satisfaction and these studies have found that most part-time faculty do not have negative attitudes of their jobs despite low pay and other non-desirable working conditions ${ }^{27}$. A recent study by Maynard and Joseph ${ }^{48}$ does seem to indicate that faculty teaching part-time by choice versus those teaching part-time involuntary have greater job satisfaction and more positive job attitudes. Both job satisfaction and attitudes are important components to motivation to teach part-time. 


\section{Motivations of Part-time Faculty to Teach}

The world of an adjunct is unique according to a nine-year part-time engineering faculty member 49 . "I was being paid 45 cents on a dollar per course, compared to the average full-time assistant professor. It would have been too depressing to factor in the same time spent on uncompensated things such as general student advising (working with students who want to get career advice from a practicing engineer) ... and student 'life-skills' counseling" (pp 14-15) ${ }^{49}$. Considering this account from a part-time faculty member it is difficult to determine why so many teach on a part-time basis. "Some see part-time teaching as a possible entry to a fulltime faculty position. Some are merely trying to bring in a little extra money. Some - attorneys, business people, police officers - are teaching as a service and a way to give back to the community that supports them. Others, such as nurses and allied health professionals, have a much needed skill to share" (p. 374) ${ }^{9}$.

According to Gappa and Leslie ${ }^{32}$ only about $15-17 \%$ of part-time faculty teach multiple courses at the same university or several universities and have the desire to teach full-time. However, in the 2004 National Study of Postsecondary Faculty, 35\% of part-time faculty respondents stated they would prefer teaching full-time. A recent study of part-time faculty at Technical Colleges in Georgia indicated that $45 \%$ of the respondents (773) would prefer to teach full-time ${ }^{9}$. It would appear that there is no consensus regarding the number of part-time faculty members who teach in hopes of achieving a full-time teaching position.

Many of the individuals who teach on a part-time basis, with no interest of teaching full-time, have employment elsewhere in professional positions. The 2004 study by the U.S. Department of Education study found that of the $65 \%$ who reported no preference to teach full-time, $72 \%$ indicated that they had a full-time position outside of the university. "They are more motivated by the intrinsic satisfactions they find in teaching than by economic or career interests" (p. 59) ${ }^{32}$. Many of these part-timers have lives that may prohibit full-time teaching and research but their dedication and knowledge is unquestionable ${ }^{50}$.

\section{Methodology}

A case study approach was used for this study. According to Merriam ${ }^{51}$, a case study provides an in-depth understanding of a situation according to those involved. A case study is a bounded case studied by the researcher through in-depth data collection to provide a rich, thick description $^{51,52}$. Within the case study, a social constructivist approach was taken to best describe the experience of each individual interviewed. According to Schwandt ${ }^{53}$, individuals construct their own knowledge and concepts based upon their own experiences, not in isolation, but with shared understandings and practices. The motivation of part-time faculty is based upon their experiences on the campus, with others, and may change over time ${ }^{9}$.

A total of 24 part-time faculty members from the schools of liberal arts and engineering/technology on this urban campus were interviewed for this study. Part-time faculty from these schools were selected based upon the large number each school employs. The literature also supported the fact that these fields of study historically have employed a large number of part-time faculty ${ }^{46}$. A purposeful sampling was selected based upon responses to a 
survey that was distributed by the deans of each school to all part-time faculty. Maximum variation sampling was used, which allowed the study to look at multiple perspectives of the participants $^{52}$. A cross-section of part-timers was selected to be interviewed based upon years of teaching part-time, highest degree attained, and additional employment. Each participant was interviewed in a location mutually agreed upon.

The data analysis was based upon guidelines adapted from Creswell ${ }^{52}$ and Stake ${ }^{54}$, and began by organizing responses in logical order, determining categories into meaningful groups, interpretation, and determining appropriate themes and patterns. The findings were then structured by the guiding research questions. Data analysis was completed utilizing the software program, NVivo. Please note that any attributions to individuals are reported under pseudonyms.

\section{Findings}

\section{Definition and Demographics}

IUPUI falls into the category of public doctoral institutions, which according to the 2003 study by the National Center for Education Statistics, employ an average of $22.2 \%$ part-time faculty on their campuses. Part-time faculty at (institutional identity left intentionally blank for peer review purposes) account for $32 \%$ of faculty, which is substantially higher than the averages reported in the 2003 study. Results of the 2003 study also indicated that $18.5 \%$ of part-time faculty have obtained a doctoral degree and 51.3\% obtained a master's degree. Of the participants for this study, four have obtained a doctoral or other terminal degree (16.6\% of study participants) and 15 obtained a master's degree (62.5\% of participants). But, it is important to note that participants for this study were selected for a purposeful sample and may not be a true reflection of the degrees obtained by all part-time faculty on the university.

\section{Employment Policies and Practices}

The review of the literature revealed employment related policies and practices are different for part-time faculty as compared to full-time and tenure track faculty. This was also the case at IUPUI where this study was conducted. Further evidence revealed there is no consistency in the practices among the two schools at this campus and even among departments within each school.

\section{Hiring and Contracting}

The responses of the part-time faculty interviewed for this study confirmed much of the literature. Respondents said that their hiring process was "informal" or "not the normal process." Respondents indicated that they learned about their part-time teaching positions in various ways; only one engineering/technology respondent indicated that an advertisement for the position had been placed in a professional journal. Most respondents said that they learned about their positions via family members and friends or through calling the school or department to inquire about any openings. Some interviewees in both schools said that they had previously had a connection with the school as a student. 
The actual interview was also most often referred to as informal by the respondents; only one engineering/technology interviewee said she had what she considered a somewhat formal interview. The respondents also said that they interviewed with only the program coordinator or the department chair. There were only two exceptions and both were liberal arts respondents. One said he was interviewed by a committee of three and the other respondent interviewed with both the program coordinator and the department chair. The respondents who were previously students on this campus said they did not have an interview and most often had been recruited by a former faculty member; one respondent said that she was asked to teach for the department at her graduation ceremony.

During the interviews, respondents indicated that they were somewhat surprised with the hiring process. Randy Smith said, "I was selected mostly on the basis of the people I knew and the credibility of my background." He also expressed both concern and amazement that no technical questions were asked to determine his knowledge in relation to the course he would be teaching. This appeared to be the normal process for hiring part-time faculty. Most respondents mentioned some type of affiliation with individuals in the department/program, either as former students or via professional affiliates. Those who did not have a direct affiliation were often referred for the part-time position by someone who did.

Well-intentioned, yet informal and ad hoc processes seem to drive last-minute decision making with regard to the hiring of part-time faculty. As with most urban campuses, student enrollment fluctuations are inherent. To complicate this even more, newly admitted students to IUPUI are not required to pay an upfront deposit to confirm their attendance. Departments can estimate the number of students who will enroll in first-year courses based on past experiences, but with no guarantee that the results will be the same. New students to IUPUI register for classes during summer orientations, which occur up until the week before classes begin. There has also been a history at IUPUI for current to students to delay registering for classes to delay payment of tuition and fees. Demand or lack of demand for classes may result in new sections needed or classes cancelled at the last minute.

In spite of the large nature of part-time staffing at IUPUI, there is no central or strategic attention to this important group. The university has very stringent guidelines for the hiring of tenuretrack faculty, but there are no centralized procedures for the hiring of part-time faculty. Based upon the responses from participants of this study, there also do not appear to be any formal application and interview requirements within either of the two schools. There are no demands on department chairs and program coordinators to interview any number of candidates before hiring a part-time person to teach a class. There also do not appear to be any deadlines enforced to hire individuals to teach.

\section{Orientation and Professional Development}

Discussion of orientation for new part-time time faculty was not prevalent in the literature. Interviewees in this study all had the opportunity to attend an orientation session when hired. Only four of the respondents had never attended an orientation session. Engineering/technology respondents said their orientation was school-based and covered policies and procedures and the online teaching tool. They were also provided a handbook that contained useful information 
according to the respondents. Two of the respondents said the session was offered in the evening and food was provided. Liberal arts respondents indicated their orientations were program-based rather than school-based with two of the department orientations mandatory for all new part-time faculty. The time commitment to attend varied among the departments in liberal arts; one program covered an entire Saturday, while another consisted of meetings throughout the semester. The material covered included policies and procedures. The respondents also commented that information was provided regarding teaching methodology, which they felt was important because so many of these faculty teach in programs with multiple-section courses required for all students at IUPUI. Based upon responses regarding orientation sessions, it was apparent that the sessions attended were only for part-time faculty and did not include full-time faculty.

An apparent strength in these two schools at IUPUI is that most part-time faculty members are getting an initial orientation to the department or program, although the topics covered in each orientation are highly variable. According to the respondents, the engineering/technology orientation, which is school-based, emphasizes processes and procedures with no information sharing on teaching methods or other classroom issues. It was not apparent that programs or departments within the school offer any additional orientation or programming to new or continuing part-time faculty. With the informality of hiring and the lack of information shared with regard to teaching it would appear that part-time faculty are left on their own with regard to the classroom. Respondents in liberal arts said that all orientation programs were program based. Teresa Donovan teaches in a program with many part-time faculty. She said that her initial orientation was on a Saturday and was structured, well-organized, and provided examples and resources including sample syllabi. She also said that there are annual workshops for continuing part-time faculty but due to her work schedule she cannot attend. While not all respondents teach in this particular program, excess of information, compared to engineering/technology, would appear to be the norm. The range, then, across programs, is a lack of information on teaching and information overload. However, across the board, there is an apparent tendency to stop ongoing professional development after this initial period.

The studies outlined in the literature review indicated mixed findings with regard to professional development opportunities for part-time faculty. Findings in this study showed mixed results with regard to participation in professional development opportunities. Nine of the liberal arts participants indicated that they have attended professional development workshops presented by the campus. Many of the liberal arts participants in this study teach courses taken by freshmen students and the campus offers a series of workshops for instructors (both part-and full-time) who teach these courses. Two participants attended. Fewer than half of the engineering/technology participants indicated attending professional development sessions. During the interviews some were even surprised that there were such opportunities available for part-time faculty. There was an interest in learning more about opportunities but participants also expressed concerns about time constraints and voiced a desire to receive a stipend for attendance.

There are real challenges in offering professional development opportunities for part-time faculty. However, the attendance at orientations for new faculty would indicate that there are apparent opportunities. While some of the participants indicated that the orientation was 
required, it was not the case for all, specifically in engineering/technology where the schoolbased orientation was not required. As discussed, many of the part-time participants in this study were hired due to subject matter expertise (especially engineering/technology). There may be a sense that subject-matter-expertise trumps teaching/pedagogical knowledge and the part-time instructor should not be required to participate in professional development. It does not appear that the culture within the schools establishes the importance of teaching and expectations in the classroom for part-time faculty.

\section{Integration of Part-time Faculty}

Integration of part-time faculty is referred in the literature as an effort to ensure that part-time faculty are supported and connected to the department and the university. Participants in this study were asked about their connection to their teaching department, the school, and the campus. The responses varied, with most faculty members stating they had a connection with their department or school but not with the campus. The liberal arts participants most often stated a connection with other part-time faculty because of the shared office space but did not express that same connection with full-time faculty. The engineering/technology participants stated a connection to the school but that was due to a previous connection prior to teaching.

An issue with lack of integration by part-time faculty is that they may only be seeing the students' educational experience from the vantage point of their own course or program and not the larger curricular or institutional goals for student learning. Pedagogical disconnection from other areas of the curriculum is significant when part-time faculty teach courses that build on each other. Lack of sharing of best practices or innovations in teaching has implications in the classroom.

\section{Perceived Issues and Concerns Regarding Part-time Faculty}

Higher education institutions employ part-time faculty for educational and economic reasons. Researchers have expressed concerns that the number of part-time faculty will continue to increase as colleges and universities continue to look for ways to cut costs. This increase in the employment of part-time faculty results in a variety of issues and concerns. Participants in this study were all exclusively part-time faculty. Administrators, staff, and full-time faculty were not included in this study. The participants were not asked questions about the perception of parttime faculty on this campus. However, some comments were gleaned from the interviews that relate to the literature on this topic and will be briefly explored in the following section, which includes the topics of contributions to student learning and contact, and undergraduate learning in the classroom.

\section{Contributions to Student Learning and Student Contact}

In this study, many of the liberal arts participants indicate that because they teach classes with many sections taken by all students, their departments take steps to insure that part-time faculty use newly selected textbooks and update their syllabus regularly. This is not the same scenario for part-time faculty teaching in engineering/technology. Many of the engineering/technology respondents did say that they bring real-life examples and experiences into the classroom; they 
felt these were very important to student learning. Based upon comments, there are several opportunities for part-time faculty to learn more about the online teaching tool used at IUPUI. Many of the participants stated they had attended sessions about this teaching tool. No one specifically mentioned that they use the tool.

Participants in this study were asked if they have any additional responsibilities in addition to teaching and not specifically about the time, if any, they spend with students outside of the classroom. Most of the responses to this question related to time spent with students, which were stated as informal in nature and related to providing career related advice and writing letters of recommendation.

Contracts for part-time faculty tend to be focused on fee-for-service for a specific class period, which may not account for student interaction needs that take place out of class (something that is different from full-time faculty who are expected to engage in activities beyond teaching). With participants indicating that they are not rewarded for any work outside of teaching a particular class, there is also no incentive to meet with students before or after class. In addition, part-time faculty may not have dedicated space to meet with students outside of the classroom. The nature of the class delivery (evenings/week-ends) may lend itself to limited out-of class interactions. Both the part-time instructor and the student may be on campus only for the purposes of the particular class and have a desire to leave the campus at the end of the class session. This segmentation of responsibilities is reinforced by the piecemeal nature of the payby-course arrangement and lack of support for work outside of the minimal commitment to conduct class and grade students. Such institutional factors create in many part-time faculty a reluctance or logistical inability to go beyond the expected minimum.

\section{Salary}

For the purposes of this study, participants were not asked about the salary they receive for teaching but the two school deans provided salary guidelines. The school of liberal arts pays $\$ 2,175$ per three credit hour course to part-time faculty without a terminal degree. Those with a terminal degree are paid $\$ 2,475$ for a three-credit hour class. It was just recently announced that all part-time faculty in the school of liberal arts would receive a $3 \%$ pay increase beginning with the spring 2011 semester and would also receive a $\$ 105$ pay supplement each semester to cover the cost of parking. The school of engineering/technology has a more elaborate pay scale for part-time faculty. The school also pays part-time faculty who possess a terminal degree more. Part-time faculty teaching for the first time, without a terminal degree, earn $\$ 2250$ for a threecredit hour course and those with a terminal degree earn $\$ 2400$. The school automatically provides salary increases after the first, second, third, and seventh years of teaching culminating in $\$ 3,000$ per three-credit hour course to those who do not possess a terminal degree and $\$ 3,150$ for those with one. There is an additional payment for those who teach a course with a lab or teach a graduate level class. The school also provides an extra payment of $\$ 100$ per semester to cover the cost of parking for part-timers who teach on the campus. The school of engineering/technology will also increase the salaries of part-time instructors by $3 \%$ beginning with the spring 2011 semester. 
The participants did have several opportunities to discuss their salaries during the interviews. When asked why they began teaching, three of the individuals indicated that one of their reasons was for the additional income. Two of the respondents work as consultants and the third respondent works part-time in addition to teaching. They looked at the income they received from teaching part-time as a stable source of revenue. One respondent said that the income she receives for teaching is enough to allow her to do the consulting work that she enjoys.

When the respondents were asked specifically about the extrinsic rewards they receive for teaching, the comments ranged from negative to positive. Five of the respondents had the more positive comments and all teach part-time in the engineering/technology school. Four of these respondents have full-time positions in addition to teaching. They looked at the money for teaching as extra income that they do not use for everyday expenditures but use for such things as vacations or the purchase of a new car. One respondent who only teaches during the two summer semesters specifically said that his salary was a pretty good amount for 12 weeks' work.

The majority of the comments were not favorable regarding salaries. Teresa Donovan was very adamant when she said, "You can do the math. The per-hour, especially when you teach a new class [is extremely low]." However, just about every participant in this study who had negative comments about their pay also went on to say that they don't teach for the money. Specifically, Brad Stout said, " . . what financial rewards!" But he went on to say that he is rewarded when students succeed. His comments seemed to sum up the opinions of many of the respondents.

When the participants in this study were asked about suggestions they had for administrators related to the pay they receive many had simple recommendations such as "pay more." Instituting annual salary increases or some type of bonus system was also mentioned by respondents. Participants understand the terms of the contract and are willing to accept it, although many would like to receive higher salaries. It is apparent that teaching part-time for the participants in this study is not about the extrinsic reward. Part-time faculty pay may not be a strategic investment by the schools, and in many cases, may compete for budget priorities with what are deemed equally--or more worthwhile activities. With what also appears to be little advance planning on the part-time faculty needs, salaries for part-time faculty may not be placed in base budgets. The nature of part-time faculty appointments is inherently designed to provide flexibility to the institution but often at the expense of adequate compensation and support for the faculty.

\section{Benefits and Support}

Part-time faculty at IUPUI are not eligible to receive health and retirement related benefits. Maggie Post, who teaches part-time at another university, said that she receives partial benefits. "I am considered a three-quarter employee, which is about three classes. There if you are only teaching two classes you can have a half-time contract and get some benefits and retirement also."

Lack of benefits for part-time faculty again may again be the result of competing budget priorities. In addition negotiations with healthcare providers may purposefully exclude extending health care benefits to part-time faculty. There may also be contractual agreements 
that do not allow the university to provide benefits to part-time faculty via other healthcare providers.

Additional discussion in the literature regarding support for part-time faculty centered around office space, availability of supplies and equipment, and secretarial support. The respondents in this study were generally satisfied with the secretarial/administrative support received; four of the respondents said that the support they receive is a motivation for their continued teaching. When talking about the administrative assistant in the school where he teaches, Tracy Allen said "I have never had her fail me. I depend on her." The literature portrays clerical support of parttime as lacking, but this finding was not expressed by respondents in this study. Department chairs and program coordinators may be treating part-time faculty strictly as professional subject matter experts who can perform with relative autonomy. The lack of involvement, however, could be a signal of neglect or lack of interest by the department chair.

\section{Advancement - No Career Ladder}

While only three liberal arts participants indicated that they would like to have a path to full-time status available, others did appear to be intrigued with the prospect of teaching full time when specifically asked. This relative lack of interest in full-time work seems to be a combination of choice and sense of the possible on the part of the participants. Many of the participants in this study have full-time positions (especially those that teach in engineering/technology) and there is no desire to put their full-time jobs on hold to teach full-time. Others expressed interest but indicated they do not have the education level to teach full-time and had no desire to continue their education. While others in the study expressed some interest in teaching full-time, they felt the university hiring model was not in their favor.

\section{Lack of Involvement in Departments}

Generally, part-time faculty do not have a voice and rarely serve on faculty governance, curriculum development, or other decision making processes that affect their work. This lack of involvement was also the norm with participants in this study; most stated that they have never been asked to serve on a program or school-based committee. One participant who teaches in liberal arts was the exception. She serves on a school-based executive committee and a diversity committee. She did say that it has been difficult for her because most of the meetings are held on days when she does not teach and is not on campus. One engineering/technology participant said he would be interested in serving on a committee if he were invited because his contributions would be valuable. He also said that he would rather do this than teach additional courses but added he would need a stipend commensurate with the time invested to do so.

Issues with lack of part-time faculty involvement could be similar to issues related to orientation and professional development. Lack of involvement could be a result of logistics and scheduling on the part of both the department and the part-time instructor, as well as the pay-by-the course piecework arrangement. As discussed, part-time faculty have other priorities and are not paid to do anything outside of teaching a class. Department chairs and program coordinators may also have no interest in planning activities at times convenient to part-time faculty (particularly evenings and week-ends) that would be outside of their normal work hours. There is also the 
perception (and perhaps the reality) that governance issues are the purview of tenured and tenure track faculty; therefore, the involvement of part-time faculty might not be valued.

\section{Motivation of Part-time Faculty to Teach}

Participants in this study had similar responses when asked why they began teaching part-time. Three participants began teaching in the first place with hopes of achieving a full-time teaching position and are still actively looking for full-time positions. Three participants also stated the extra income they would earn by teaching part-time served as a motivation. Specifically, two of the participants have a consulting business and the income they earn from teaching serves as a guaranteed base income for them. Participants in this study included professionals, especially in the school of engineering/technology, but no participants in this study indicated that service or giving back to the community was a reason they originally chose to teach. The most common responses to the question were in the category of teaching and learning: participants indicated that they wanted to share their experiences by taking their real-world experiences into the classroom to share with students and wanted to foster or stimulate their own learning.

Participants in this study stated several other reasons why they first began to teach part-time. Several study participants stated either free time or flexibility as a reason. Two participants in particular valued the fact that they could choose the times to teach and could work around the schedules of their families. Three participants said they were looking for something to do with their free time that was more intellectually challenging. Two participants indicated that autonomy or control was an important reason. Specifically, one participant who teaches parttime in engineering/technology said his main motivation for teaching part-time was having better control over his own performance. He said that in his full-time position outside of the university he manages a number of individuals and his performance evaluation is based at least $95 \%$ in the performance and outcomes of the individuals he manages. Bob Oldham went on to say, "if they don't do their job then I am responsible because I'm responsible for making sure they do their job." In teaching part-time he said that he has control of his performance. Interestingly, however, he did go on to say that he did not see the measure of his performance as including whether or not the "kids" learn or not because "once you've done everything you can ... it's up to them if they learn." Prestige and affiliation with the university was another reason stated by three participants for teaching part-time. This included interaction with university colleagues and stimulus for their own learning provided by the university setting through cultural and other opportunities.

Participants were also asked about why they continue to teach part-time and the rewards they receive for teaching. The most common responses were intrinsic in nature. Most often comments related to interaction with students and the "aha" moment. The connection with the students is a very strong motivator for participants in this study. Participants also had comments about the affiliation with the university. Four participants said that teaching part-time at IUPUI has proved to be beneficial in several ways. David Grant has collaborated with others in his department to provide training outside of the university (which also results in additional income). Nancy Kirkland said that her affiliation with the university has opened doors to access archives for her own personal research. The prestige of the affiliation with the university was mentioned 
by several participants, who enjoyed a higher perceived social status connected with their university affiliation.

\section{Recommendations}

\section{For Administrators}

Many studies indicate the growing and constant use of part-time faculty on college campuses. Part-time faculty need to be highly valued as a strategic priority by institutional leadership. Many of the participants discussed salary and benefits when asked specifically for recommendations for administrators.

- Develop a pay structure with a greater connection to teaching evaluations. Look for ways to offer benefits to part-time faculty. While it may be difficult to do either of these, greater communication with part-time faculty to discuss financial constraints would be beneficial in making part-time faculty feel connected and have a greater understanding of the university's financial picture.

- Formalize the hiring and orientation process. While hiring may be done last minute due to enrollment fluctuation, department chairs/program coordinators should continually interview prospects for part-time teaching positions so that they have a pool to select from when the need arises. They should also make every attempt to use past enrollment patterns to make appointments in a timely way.

- Provide professional development opportunities at times convenient for part-time faculty. Offer a stipend for participation. Consider the development of online tools specifically for part-time faculty.

- Provide a recognition program (this does not have to be a monetary award but could be a luncheon or other ceremony).

- Increase the connection of part-time faculty with the department and solicit participation in collaborative projects.

\section{For Part-time Faculty}

The motivations for teaching vary from person to person as has been described throughout this study, but there appears to be an apparent lack of communication on many issues. Part-time faculty should be proactive in seeking information.

- Be clear about reasons for seeking part-time employment.

- Recognize the staffing, financial, space, and resource constraints inherent in the role.

- Be proactive in asking questions and seeking reasonable assistance and advice. Ask about opportunities for professional development, if interested.

- Offer to use subject-matter-expertise to enhance the course or curriculum, as appropriate.

- Ask for meetings to discuss student evaluations.

- Seek ways to understand the broader institutional culture and context and how particular courses or programs relate.

For Future Research 
Subject matter for future research will be in two categories: one for IUPUI and the other for broader research. Recommendations for IUPUI should also be considered by any institution that seeks to learn more about the part-time faculty teaching on their campus.

- A comprehensive survey of part-time faculty and the administrators who hire them is recommended to gather information related to the these processes.

- Institutions should be encouraged to conduct regular, in-depth studies of part-time faculty, university wide, drawing upon the motivation theories in this study.

- Colleges and universities should track retention/turnover rates of part-time faculty to ascertain why they leave? What is the cost associated with turnover? What steps can be taken to alleviate turnover, if deemed an issue?

- This study revealed that many of the part-time faculty teaching are former students of the programs in which they are teaching. Institutions might seek to learn how often former students are hired to teach part-time after graduation and to consider whether or not this practice serves as an asset.

Areas of recommended research for the broader higher education community include:

- Identification of best practices in part-time teaching by institutional type, in particular four-year institutions.

- The impact of part-time faculty on the quality of teaching and learning, including measures such as student satisfaction, performance, retention, and persistence.

- Long-term implications of this staffing model on American higher education's competitiveness in a global marketplace.

\section{Conclusion}

While they had varied reasons for teaching part-time basis, it was apparent that study participants seemingly wanted only the best for their students. The lack of consistency in the hiring process was an obvious flaw in the system. This university, as well as most others, relies heavily on part-time faculty to teach. But, policy guidelines and procedures are lacking. Every participant in this study had a different experience. Interestingly, all participants were concerned about the lack of procedures in their own hiring compared with the processes of hiring full-time tenuretrack faculty. There are many reasons associated with this, but on the surface, it is apparent that there are different standards for part-time faculty compared to full-time tenured and tenure track faculty. That sentiment was felt by participants in this study. This same informality appeared to carry over into course evaluations. While all but one participant stated they receive student evaluations each semester, there was no process for discussing the results and obtaining feedback.

The growth of literature on part-time faculty is occurring. In the early days of research on parttime faculty, the literature focused on the negative aspects of part-time faculty. More recent studies have focused on the inconsistent treatment of part-time faculty as well as the benefits of part-time faculty. However, there have also been more studies on the effects of part-time faculty on graduation rates and student success. While much of the literature remains focused on part- 
time faculty teaching at community colleges, there has also been an expansion of research within the context of four-year universities. Universities are also completing studies that look at the satisfaction of their part-time faculty, and this talent management strategy will continue to be an ever-present challenge in applied and professional fields such as engineering/technology.

\section{Bibliography}

1. National Center for Education Statistics (2005). 2004 national study of postsecondary

Faculty (NSOPF:04) report on faculty and instructional staff in fall 2003

(NCES 2005-172). Washington, DC: U. S. Department of Education.

Retrieved August 1, 2008 from http://nces.ed.gov/pubsearch

2. Gappa, J. M. (2008). Today's majority: faculty outside the tenure system. Change, 40(4), 50-53.

3. Rhoades, C. (1996). Reorganizing the faculty workforce for flexibility: part-time professional labor. The journal of higher education, 67(6), 626-659.

4. Gappa, J. M. (2000). The new faculty majority: Somewhat satisfied but not eligible for tenure. In L. S. Hagedorn (Ed.). New Directions for Institutional Research: Vol. 105. Overcoming Survey Research Problems (77-86). Hoboken, NJ: Wiley Periodicals.

5. Green, D. W. (2007). Adjunct faculty and the continuing quest for quality. In R. L. Wagoner (Ed.), New Directions for Community Colleges: Vol. 140. The current landscape and changing perspectives of part-time faculty (pp. 29-40). Hoboken, NJ: Wiley Periodicals.

6. Nutting, Maureen Murphy (2003). Part-time faculty: Why should we care. In E. Benjamin (Ed.), New Direction for Higher Education: Vol. 123. Exploring the role of contingent instructional staff in undergraduate learning (pp. 33-39). Hoboken, NJ: Wiley Periodicals.

7. Schuetz, P. (2002). Instructional practices of part-time and full-time faculty. In C. L. Outcalt (Ed.), New Directions for Community Colleges: Vol 118. Community college faculty: characteristics, practices, and challenges (pp. 39-46). Hoboken, NJ: Wiley Periodicals.

8. Valadez, J. R. \& Anthony, J.S. (2001). Job satisfaction and commitment of two-year college part-time faculty. Community college journal of research and practice, 25 (2), 97-108.

9. Wallin, Desna L. (2004). Valuing professional colleagues: adjunct faculty in community and technical colleges. Community college journal of research and practice, 28, 373-391.

10. Gappa, J. M., \& Leslie, D. W. (1993). The invisible faculty. San Francisco: Jossey-Bass.

11. Leslie, D. W. (Ed.). (1998). The growing use of part-time faculty: understanding causes and effects. San Francisco: Jossey-Bass.

12. Clark, B. R. (Ed.). (1987). The academic profession: national, disciplinary, and institutional settings. Los Angeles: University of California Press.

13. Brawer, F. B., \& Cohen, A. M. (1982). The American community college. San Francisco: Jossey-Bass.

14. Schuster, J. H. \& Finkelstein, M. J. (2006). The American faculty: the restructuring of academic work and careers. Baltimore: Johns Hopkins University Press.

15. American Federation of Teachers. (2001). Statement on part-time faculty employment. Washington, DC: Author. Retrieved November 8, 2001 from http://www.aft.org/higher_ed/parttimefac/pattime.html.

16. Benjamin, E. (2002). How over reliance on contingent appointments diminishes faculty involvement in student learning. Peer Review, 1(5), 4-10.

17. Langenberg, D. N. (1998). The subfaculty. In D. W. Leslie (Ed.), New directions for higher education: Vol. 104. The growing use of part-time faculty: understanding causes and effects (pp. 39-44). San Francisco: JosseyBass.

18. Tuckman, H. P., Caldwell, J., \& Volger, W. (1978). Part-timers and the academic labor market of the eighties. The American sociologist, 13(4), 184-195.

19. Banachowski, G. (1996). Perspectives and perceptions: The use of part-time faculty in community colleges. Community college review, 24(2), 49-63.

20. Jacoby, D. (2006). Effects of part-time faculty employment on community college graduation rates. Journal of higher education, 77(6), 1081-1103. 
21. Curtis, J. W. \& Jacobe, M. F. (2006). Consequences: an increasingly contingent faculty. In AAUP contingent faculty index. Washington, DC: American Association of University Professors.

22. Dedman, D., \& Pearch, W. J. (2004). Perspectives on adjunct and other non-tenured faculty. The Community College Enterprise, 10(1), 23-33.

23. Tam, T., Jacoby, D. (2009). What we can't say about contingent faculty. Academe, 94(6) 19-22.

24. Levin, J. S. (2007). Multiple judgments: institutional context and part-time faculty. In R.

L. Wagoner (Ed.), New directions for higher education: Vol. 140. The current

landscape and changing perspectives of part-time faculty (pp. 15-20). Hoboken, NJ: Wiley Periodicals.

25. Stephens, A., \& Wright, S. W. (1999). The part-time faculty paradox. Community college week, 11(13), 6.

26. Van der Vorm, P. T. (2001). The well-tempered search: hiring faculty and administrators for mission, Academe, 87(3), 34-36.

27. Feldman, D. C., \& Turnley, W. H. (2001). A field study of adjunct faculty: The impact of career stage on reactions to non-tenure track jobs. Journal of Career Development, 28(1), 1-16,

28. Wyles, B. A. (1998). Adjunct Faculty in the Community College. In D. W. Leslie (Ed.), New directions for higher education: Vol.104. The growing use of part-timefaculty: understanding causes and effects (pp. 89-93). San Francisco: Jossey-Bass.

29. Hudd, S. S. , Apgar, C. Bronson, E.F., Lee, R.G. (2009). Creating a campus culture of integrity: comparing the perspectives of full-and part-time faculty. The journal of higher education, $80(2)$, 146-147.

30. Grant, M. R., \& Keim, M. C. (2002). Faculty development in publicly supported two-year colleges. Community college journal of research and practice, 26, 793-807.

31. Leslie, D. M., \& Gappa, J. M. (2002). Part-time faculty: Competent and committed. New directions for community colleges: Vol. 118. Community college faculty: characteristics, practices, and challenges (pp. 5968). Hoboken, NJ: Wiley Periodicals.

32. Gappa, J. M., \& Leslie, D. W. (1997). Two faculties or one? The conundrum of part-timers in a bifurcated workforce. Washington, D. C.: American Association for Higher Education.

33. American Historical Society (2000). Statement on the growing use of part-time faculty. Washington, DC: Author. Retrieved November 14, 2000 from http://www.theaha.org/info/adjunct.html.

34. Haeger, J. D. (1998). Part-time faculty, quality programs, and economic realities. In J. W. Leslie (Ed.). New directions for higher education: Vol.104. The growing use of Part-time faculty: understanding causes and effects (pp. 81 - 88). San Francisco: Jossey-Bass.

35. Keim, M. C., \& Biletzky, P. E. (1999). Teaching methods used by part-time community college faculty. Community college journal of research and practice, 23(8), 727-737.

36. Roueche, J. E., Roueche, S. D., \& Milliron, M. D. (1998). Strangers in Their Own Land. Washington, DC: Community College Press.

37. Hellman, C.M. (1998). Faculty evaluation by students: a comparison between full-time and adjunct faculty. Journal of applied research in the community college, 6, 45-50.

38. Landrum, R. E. (2009). Are there instructional differences between full-time and part-time faculty? College Teaching, 57(1), 23-36.

39. Schuster, J. H. (2003). The faculty makeover: what does it mean for students? In E. Benjamin (Ed.), New dimensions for higher education: Vol. 123. Exploring the role of contingent instructional staff in undergraduate learning (pp. 15-22). Hoboken, NJ: Wiley Periodicals.

40. Umbach, P. D., (2007). How effective are they? Exploring the impact of contingent faculty on undergraduate education. The review of higher education, 30(2), 91-123.

41. Jacobs, F. (1998). Using part-time faculty more effectively. In D. W. Leslie (Ed.), New Directions for higher education: Vol. 104. The growing use of part-time faculty: Understanding causes and effects (pp. 9-18). San Francisco: Jossey-Bass.

42. Burgess. L. A., \& Samuels, C. (1999). Impact of full-time versus part-time instructor status in college student retention and academic performance. Community College Journal of Research and Practice, 23(5), 487-498.

43. Boyland, H.R. (2002). What works: a guide to research-based best practices in developmental education. Boone, NC: Appalachian State University, Continuous Quality Improvement Network with the National Center for Developmental Education.

44. Krier, D., \& Staples, W. G. (1993). Seen but unseen: Part-time faculty and institutional surveillance and control. American socialist, 24, 119-134.

45. Monks, J. (2009). Who are the part-time faculty? Academe, 95(4), 33-37.

46. Gappa, J. M. (2008). Today's majority: faculty outside the tenure system. Change,40(4), 50-53. 
47. Sommer, B. (1994). Reorganizing academes' other faculty. Planning for higher Education, 22, 7-10.

48. Maynard, D. C. \& Jospeh, T.A. (2006). Are all part-time faculty underemployed; the Influence of faculty status preference on satisfaction and commitment. Higher education, 55(2), pp. 139-154.

49. Sputo, T. (2006). Care and feeding of instructions for engineering adjunct faculty. Journal of professional issues in engineering education and practice, 14-17.

50. Nutting, Maureen Murphy (2003). Part-time faculty: Why should we care. In E. Benjamin (Ed.), New Direction for Higher Education: Vol. 123. Exploring the role of contingent instructional staff in undergraduate learning (pp. 33-39). Hoboken, NJ: Wiley Periodicals.

51. Merriam, S. B. (1998). Qualitative research and case study applications in education. San Francisco: JosseyBass.

52. Creswell, J. W. (1998). Qualitative inquiry and research design: choosing among five traditions. Thousand Oaks, CA: Sage.

53. Schwandt, T. A. (2000). Three epistemological stances for qualitative inquiry. In Denzin, N. K. \& Lincoln, Y. S. (Eds.). Handbook of qualitative research, second edition. Thousand Oaks, CA: Sage Publications, Inc.

54. Stake, R. (1995). The art of case study research. Thousand Oaks, CA: Sage. 